\title{
Upaya Meningkatkan Hasil Belajar Struktur Tubuh Manusia melalui Model Snowball Throwing Bagi Siswa SD
}

\author{
Hartini \\ UPK Jatilawang Banyumas \\ Jl. Pramuka, Tunjung Wetan, Tunjung, Kec. Jatilawang, Kabupaten Banyumas, Jawa \\ Tengah \\ Email: bdmartono7@gmail.com
}

\begin{abstract}
Abstrak
Peneitian ini dilatar belakangi adalah rendahnya hasil belajar mata pelajaran IPA tentang struktur tubuh manusia dan fungsinya bagi siswa kelas IV SD Negeri 2 Jatilawangsemester ganjil tahun pelajaran 2014/2015. Tujuan penelitian ini adalah untuk memperbaiki hasil belajar siswa. Pelaksanaan penelitian dilakukan melalui dua siklus yaitu melalui siklus I dan siklus II menggunakan model pembelajaran Snowball Throwing. Pada studi awal nilai rata-rata 56,85, siklus I menjadi 72,85. Kemudian pada siklus II meningkat optimal menjadi 82,28. Prosentase ketuntasan studi awal 25,71\% lalu siklus I menjadi $77,15 \%$. Kemudian pada siklus II meningkat menjadi 94,28\%. Prosentase tidak tuntas pada pra siklus $74,29 \%$ lalu siklus I menurun menjadi $22,85 \%$. Kemudian pada siklus II menjadi 5,72\%. Kesimpulan penerapan model Snowball Throwing Peningkatan Hasil Belajar Struktur Tubuh Manusia Dan Fungsinya Bagi Siswa Kelas IV SD Negeri 2 Sudagaran, Kabupaten Banyumas Tahun Pelajaran 2014/2015.
\end{abstract}

Kata kunci: Snowball Throwing, hasil belajar, Struktur Tubuh Manusia Dan Fungsinya.

\begin{abstract}
This research is motivated by the low learning outcomes of natural science subjects about the structure of the human body and its functions for fourth grade students of SD Negeri 2 Jatilawangsang odd semester 2014/2015 academic year. The purpose of this study is to improve student learning outcomes. The research was carried out through two cycles, namely through the first cycle and second cycle using the Snowball Throwing learning model. In the initial study the average value was 56.85 , the first cycle being 72.85 . Then in the second cycle increased optimally to 82.28. The percentage of completeness of the initial study was $25.71 \%$ then the first cycle became $77.15 \%$. Then in the second cycle increased to $94.28 \%$. The percentage of incomplete in the pre cycle $74.29 \%$ then the first cycle decreased to $22.85 \%$. Then in the second cycle to $5.72 \%$. Conclusion of the application of the Snowball Throwing model Improved Learning Outcomes of the Human Body Structure and Its Functions for Grade IV Students of SD Negeri 2 Sudagaran, Banyumas Regency 2014/2015 Academic Year.
\end{abstract}

Keywords: Snowball Throwing, learning outcomes, Human Body Structure and Its Functions.

\section{PENDAHULUAN}

Pada mata pelajaran IPA di kelas IV tentang struktur tubuh manusia dan fungsinya, siswa kurang antusias dalam mengikuti pelajaran. Banyak siswa yang bercerita sendiri, ada yang mengantuk ada pula yang terlihat fokus mendengarkan tetapi ketika diberi pertanyaan 
siswa tersebut kebingungan. Apalagi setelah peneliti mendapatkan hasil belajar siswa melalui pemberian tes evaluasi yang menunjukkan sangat rendah dan jauh dari Kriteria Ketuntasan Minimal (KKM). KKM yang ditentukan adalah $\geq 70$ dan ternyata dari 35 siswa hanya 9 siswa yang tuntas atau 25,71\% sedangkan yang belum tuntas adalah sejumlah 26 siswa atau $74,29 \%$. Peneliti merasa pembelajaran yang dilakukan belum bisa efektif, menarik dan menghasilkan output yang diharapkan. Berbekal dari pengalaman dan pengetahuan peneliti berencana untuk melakukan perbaikan dengan mengidentifikasi faktor-faktor penyebabnya dan mencari alternatif pemecahan masalah. Peneliti juga berkonsultasi dengan teman sejawat dan kepala sekolah tentang rencana pelaksanaan Penelitian Tindakan Kelas (PTK). Peneliti akan merubah model pembelajaran sehingga akan memvariasi menggunakan model pembelajaran Snowball Throwing yang akan dilaksanakan bersiklus yaitu siklus I dan siklus II. Snowball Throwing adalah model pembelajaran dengan penyampaian materi secara klasikal, lalu pembentukan kelompok.Guru memanggil masing-masing ketua kelompok dan diberi materi tertentu untuk dibahas dengan anggotanya. Tiap kelompok membuat pertanyaan dan diberikan ke kelompok lain untuk dijawb. Kelompok lain menjawab secara bergantian. Setelah itu guru dan siswa melakukan penyimpulan materi, refleksi dan evaluasi. Dengan penerapan model tersebut diharapkan hasil belajar siswa kelas IV pada mata pelajaran IPA tentang struktur tubuh manusia dan fungsinya semester ganjil tahun pelajaran 2014/2015 dapat meningkat sesuai dengan Kriteria Ketuntasan Minimal (KKM) yang ditentukan yaitu $\geq 70$

Menurut Sri Anitah W, dkk dalam teori Insight yang dikutip dari modul Strategi Pembelajaran di SD S1 PGSD Universitas Terbuka (2011: 2.16) belajar adalah mengubah pemahaman siswa. Perubahan akan terjadi apabila siswa menggunakan lingkungan. Belajar adalah suatu proses yang bersifat eksploratif, imajinatif, dan kreatif. Selain pendapat di atas ada pula pendapat dari Slameto (2008) yang dikutip pada jurnal paedagog dari Sujoto (2012: 50) bahwa belajar merupakan suatu proses usaha yang dilakukan seseorang untuk memperoleh suatu perubahan tingkah laku yang baru secara keseluruhan, sebagai hasil pengalamannya sendiri dalam berinteraksi dengan lingkungan.

Berdasarkan uraian di atas peneliti menyimpulkan bahwa belajar adalah suatu perubahan kepribadiaan atau perilaku seseorang dari proses pengalaman, kecakapan atau kebiasaan. Untuk itu menurut Gagne (1979) (2011: 2.19) menyatakan bahwa ada lima tipe hasil belajar yang dicapai oleh siswa. Kemudian pendapat lain dari Harun Rasyid (2007: 13) yang dikutip pada jurnal paedagog dari Herry Nuryanto Widodo (2012: 67) bahwa $\underline{\text { hasil belajar akan bermanfaat bagi masyarakat bila pada lulusan memiliki perilaku dan }}$ 
pandangan yang positif dalam ikut mensejahterahkan dan menentramkan masyarakat. Menurut Abineno J.I yang dikutip dari situs http://pengertiandefinisi.com/pengertianmanusia-menurut-para-ahli/ tanggal 28 September 2016 pukul 16.15 bahwa manusia adalah "tubuh yang dilengkapi dengan jiwa/berjiwa" dan bukan "jia abadi yang berada atau pun yang terbungkus di dalam sebuah tubuh/badan yang fana / tidak nyata". Tulang-tulang saling berhubungan membentuk rangka. Jalinan antar satu rangka dengan rangka lainnya membentuk system rangka.

\section{METODE PENELITIAN}

Pengertian mtode Model Pembelajaran Snowball Throwing Kisworo (2008) yang dikutp dari situs http://globallavebookx. blogspot.co.id /2015/03/ pengertian- modelpembelajaran-snowball. html tanggal 27 September 2016 pukul 1.14 mengemukakan bahwa model pembelaja-ran Snowball throwing adalah suatu metode pembelajaran yang diawali dengan pembentukan kelompok yang diwakili ketua kelompok untuk mendapat tugas dari guru kemudian masing-masing siswa membuat pertanyaan yang dibentuk seperti bola (kertas pertanyaan) lalu dilempar ke siswa lain yang masing-masing siswa menjawab pertanyaan dari bola yang diperoleh. Kegiatan melempar bola pertanyan ini akan membuat kelompok menjadi dinamis, karena kegiatan siswa tidak hanya berpikir, menulis, bartanya, atau berbicara. Akan tetapi mereka juga melakukan aktivitas fisik yaitu menggulung kertas dan melemparkannya pada siswa lain. Dengan demikian, tiap anggota kelompok akan mempersiapkan diri karena pada gilirannya mereka harus menjawab pertanyaan dari temannya yang terdapat dalam bola kertas.Model pembelajaran snowball throwing ini guru berusaha memberikan kesempatan kepada siswa untuk mengembangkan keterampilan menyimpulkan isi berita atau informasi yang mereka peroleh dalam konteks nyata dan situasi yang kompleks. Guru juga memberikan pengalaman kepada siswa melalui pembelajaran terpadu dengan menggunakan proses yang saling berkaitan dalam situasi dan konteks komunikasi alamiah baik sosial, mau pun dalam lingkungan pergaulan.

Tahapan dan Langkah-Langkah Model Pembelajaran Snowball Throwing, menurut Suprijono (2009:128) dan Saminanto (2010:37) yang dikutip dari situs http://mgmppknkabkuburaya.blogspot.co.id/2012/08/artikel-3-penerapan-metodesnowball.html tanggal 27 September 2016 pukul 1.16 langkah-langkah pembelajaran metode snowball throwing adalah:

a) Guru menyampaikan materi yang akan disajikan, dan KD yang ingin dicapai.

b) Guru membentuk siswa berkelompok, lalu memanggil masing-masing ketua kelompok 
untuk memberikan penjelasan tentang materi.

c) Masing-masing ketua kelompok kembali ke kelompoknya masing-masing, kemudian menjelaskan materi yang disampaikan oleh guru kepada temannya.

d) Kemudian masing-masing siswa diberikan satu lembar kertas kerja, untuk menuliskan satu pertanyaan apa saja yang menyangkut materi yang sudah dijelaskan oleh ketua kelompok.

e) Kemudian kertas yang berisi pertanyaan tersebut dibuat seperti bola dan dilempar dari satu siswa ke siswa yang lain selama \pm 5 menit.

f) Setelah siswa dapat satu bola/satu pertanyaan diberikan kesempatan kepada siswa untuk menjawab pertanyaan yang tertulis dalam kertas berbentuk bola tersebut secara bergantian.

g) Evaluasi

h) Penutup

\section{HASIL DAN PEMBAHASAN}

Siklus I

Pada siklus I tentang struktur tubuh manusia dan fungsinya Mata pelajaran IPA kelas IV SD Negeri 2 Jatilawangpeneliti mendapatkan data sebagai berikut:

1) Nilai rata-rata siswa studi awal 56,85 dan pada siklus I meningkat menjadi 72,85 .

2) Prosentase ketuntasan studi awal $25,71 \%$ dan pada siklus I meningkat menjadi $77,15 \%$.

3) Prosentase tidak tuntas pada pra siklus $74,29 \%$ dan pada siklus I menurun menjadi $22,85 \%$.

4) Siswa yang tuntas studi awal 9 siswa meningkat pada siklus I menjadi 27 siswa.

5) Siswa yang belum tuntas studi awal 26 siswa menurun pada siklus I menjadi 8 siswa.

Pada pelaksanaan siklus I, peneliti mendapatkan data hasil refleksi bahwa masih ada siswa yang belum paham terhadap materi yang disampaikan. Hal tersebut terbukti pada siklus I masih ada 8 siswa yang belum tuntas belajar atau 22,85\%. Dengan demikian perbaikan pembelajaran pada siklus I dinyatakan belum berhasil dan peneliti akan berupaya menerapkan penggunaan model Snowball Throwing yang lebih menarik lagi.

\section{Siklus II}

Pada siklus II didapatkan data perubahan sebagai berikut:

a. Nilai rata-rata siswa studi awal 56,85 lalu siklus I menjadi 72,85. Kemudian pada siklus II hasil belajar siswa meningkat optimal menjadi 82,28. 
b. Prosentase ketuntasan studi awal $25,71 \%$ lalu siklus I menjadi 77,15\%. Kemudian pada siklus II meningkat menjadi 94,28\%.

c. Prosentase tidak tuntas pada pra siklus $74,29 \%$ lalu siklus I menurun menjadi $22,85 \%$. Kemudian pada siklus II menjadi 5,72\%.

d. Siswa yang tuntas studi awal 7 siswa meningkat pada siklus I menjadi 27 siswa. Kemudian pada siklus II menjadi 33 siswa.

e. Siswa yang belum tuntas studi awal 26 siswa menurun pada siklus I menjadi 8 siswa.

Pada perbaikan pembelajaran siklus II pada mata pelajaran IPA tentang struktur tubuh manusia dan fungsinya dengan penggunaan model pembelajaran Snowball Throwing sudah sangat tepat karena telah terbukti dapat meningkatkan hasil belajar siswa hingga ketuntasan belajar siswa mencapai $94,28 \%$ sehingga peneliti mengakhiri perbaikan pembelajaran ini hanya sampai pada siklus II.

Pada siklus I peneliti melaksanakan perbaikan pembelajaran dengan menggunakan model pembelajaran Snowball Throwing. Model pembelajaran Snowball Throwing adalah model pembelajaran dengan penyampaian materi secara klasikal, lalu pembentukan kelompok.Guru memanggil masing-masing ketua kelompok dan diberi materi tertentu untuk dibahas dengan anggotanya. Tiap kelompok membuat pertanyaan dan diberikan ke kelompok lain untuk dijawb. Kelompok lain menjawab secara bergantian. Setelah itu guru dan siswa melakukan penyimpulan materi, refleksi dan evaluasi.

Pada perbaikan pembelajaran siklus I diperoleh data nilai rata-rata siswa studi awal 56,85 lalu siklus I menjadi 72,85. Prosentase ketuntasan studi awal 25,71 \% lalu siklus I menjadi 77,15. Prosentase tidak tuntas pada pra siklus $74,29 \%$ lalu siklus I menurun menjadi 22,85\%. Siswa yang tuntas studi awal 9 siswa meningkat pada siklus I menjadi 27 siswa. Siswa yang belum tuntas studi awal 26 siswa menurun pada siklus I menjadi 8 siswa. Pengamatan peneliti pada siklus I ini tidak meleset karena seperti yang disampaikan diatas pada siklus I terjadi peningkatan pembelajaran. Metode Snowball Throwing dapat meningkatkan hasil belajar siswa kelas IV, namun karena peningkatan yang terjadi belum sesuai harapan maka peneliti melanjutkan ke siklus II.Pada siklus I pembelajaran IPA mengenai struktur tubuh manusia dan fungsinya menunjukkan hasil belajar siswa mengalami peningkatan, dibawah ini adalah perbandingan dari studi awal dan siklus I dalam bentuk tabel dan grafik berikuti ini. Berikut rekapitulasi hasil belajar dari prasiklus, siklus I dan siklus II dapat dilihat pada gambar di bawah ini. 


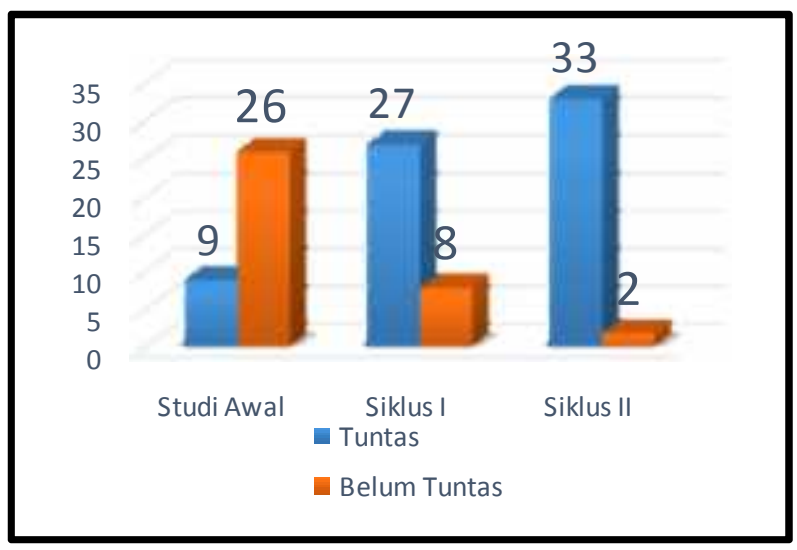

Gambar 4 Diagram Ketuntasan pada Prasiklus, Siklus I, dan Siklus II

Pada siklus II ini, siswa lebih aktif dan semangat karena alat peraga dan media yang digunakan mencukupi kebutuhan siswa sehingga sangat membantu pemahaman siswa dalam mempelajari materi. Karena siswa fokus dan aktif saat pembelajaran, maka hasil belajar siswa yang diperoleh pada siklus II sangat baik. Hal tersebut dibuktikan dengan nilai rata-rata siswa studi awal 56,85 lalu siklus I menjadi 72,85. Kemudian pada siklus II hasil belajar siswa meningkat optimal menjadi 82,28. Prosentase ketuntasan studi awal 25,71\% lalu siklus I menjadi 77,15\% . Kemudian pada siklus II meningkat menjadi 94,28 $\%$. Prosentase tidak tuntas pada pra siklus $77,29 \%$ lalu siklus I menurun menjadi $22,85 \%$. Kemudian pada siklus II menjadi 5,72\%. Siswa yang tuntas studi awal 9 siswa meningkat pada siklus I menjadi 27 siswa. Kemudian pada siklus II menjadi 33 siswa. Siswa yang belum tuntas studi awal 26 siswa menurun pada siklus I menjadi 8 siswa. Kemudian pada siklus II menjadi 2 siswa.

Dengan demikian model pembelajaran snowball throwing terbukti dapat meningkatkan hasil belajar siswa kelas IV pada mata pelajaran IPA tentang struktur tubuh manusia dan fungsinya, Walaupun pada siklus II masih ada 2 siswa yang belum tuntas tetapi rata-rata kelas yang diperoleh telah mencapai 82,28 sehingga perbaikan pembelajaran pada siklus II dinyatakan berhenti.

\section{KESIMPULAN}

Dari uraian diatas, maka kesimpulanya adalah penggunaan model Snowball Throwing dapat meningkatkan hasil belajar siswa pada pembelajaran IPA tentang struktur tubuh manusia dan fungsinya bagi siswa kelas IV di SD Negeri 2 Jatilawangpada semester ganjil tahun pelajaran 2014/2015. Hal tersebut dibuktikan dengan ketuntasan hasil belajar siswa pada prasiklus yaitu 9 siswa atau $25,71 \%$ dengan rata-rata kelas 56,85. Kemudian 
pada siklus I ketuntasan belajar siswa meningkat menjadi 27 siswa atau 77,15\% dengan rata-ata kelas 72,85. Pada siklus II ketuntasan belajar siswa semakin meningkat menjadi 33 siswa atau 94,28\% dengan rata-rata kelas 82,28 . Selain peningkatan hasil belajar, pada proses perbaikan pembelajaran ini juga telah terjadi penurunan ketidaktuntasan. Hal ini dapat dibuktikan bahwa siswa yang belum tuntas pada prasiklus adalah sejumlah 26 siswa atau $74,29 \%$ Kemudian pada siklus I siswa yang belum tuntas menurun menjadi 8 siswa atau $22,85 \%$. Pada siklus II juga kembali terjadi penurunan siswa yang belum tuntas yaitu hanya 2 siswa atau $5,72 \%$.

\section{SARAN}

Perlu diperdalam penelitian tindakan kelas yang berkaitan tentang penggunaan model Snowball Throwing

\section{DAFTAR PUSTAKA}

Budiningsih, Asri. (2012). Peningkatan Mutu Dan Minat Belajar IPS Melalui Cooperative Learning Model STAD Di Kelas 7A SMPN 1 Ajibarang. Jurnal Paedagog, 14 (7), hal. 4.

Direktorat Ketenagaan. (2009). Modul 8. Kurikulum Sekolah Dasar: Perspektif Pendidikan SD. Jakarta: Penerbit Universitas Terbuka.

Gagne. (2011). Modul 2. Pembelajaran Di Sekolah Dasar: Strategi Pembelajaran. Jakarta: Pusat Penerbit Universitas Terbuka.

Ibrahim, Muslim. (2012). Penerapan Model Pembelajaran Research Group Dalam Meningkatkan Hasil Belajar Sains Pada Siswa Kelas 8A SMP Negeri 2 Karanglewas Kabupaten Banyumas. Jurnal Paedagog, 14 (7), hal. 50.

Joni. (2011). Modul 1. Hakikat Strategi Pembelajaran: Strategi Pembelajaran di SD. Jakarta: Penerbit Universitas Terbuka

Kurikulum 2004. (2012). Modul 2. Pendekatan Dalam Pembelajaran IPA SD: Pembelajaran IPA di SD. Tangerang Selatan: Penerbit Universitas Terbuka.

Permendiknas No. 22 tahun 2006. (2016). Penggunaan Model Eksperimen Untuk Meningkatkan Hasil Belajar IPA Bagi Siswa Kelas V SDN Pesantren Tambak. TUT WURI Jurnal Penelitian dan Pengembangan Pendidikan. 4 (1), hal.77.

Rasyid Harun. (2012). Penerapan Model Pembelajaran Kooperatif Tipe STAD Untuk Meningkatkan Prestasi Belajar Matematika Pada Siswa Kelas VIIG SMPN 2 Wangon Semester Genap Tahun Pelajaran 2010/2011. Jurnal Paedagog, 14 (7), hal. 67. 
Slameto. (2012). Penerapan Model Pembelajaran Research Group Dalam Meningkatkan Hasil Belajar Sains Pada Siswa Kelas 8A SMP Negeri 2 Karanglewas Kabupaten Banyumas. Jurnal Paedagog, 14 (7), hal. 50

Sudjana. (2009). Modul 1. Konsep Dasar PKM. Pemantapan Kemampuan Mengajar (PKM)-PGSD. Jakarta: Pusat Penerbit Universitas Terbuka.

TIM-FKIP. (2012). Modul 1. Konsep Dasar PKM: Pemantapan Kemampuan Mengajar $(P K M)-P G S D$. Tangerang Selatan: Pusat Penerbit Universitas Terbuka.

W.Anitah, Sri, dkk. (2011). Modul 2. Pembelajaran Di Sekolah Dasar: Strategi Pembelajaran di SD. Jakarta: Pusat Penerbit Universitas Terbuka.

Abineno J.I. Diunduh tanggal 28 September 2016 pukul 16.15 dari situs http://pengertiandefinisi.com/pengertian-manusia-menurut-para-ahli/

Kisworo (2008). Diunduh tanggal 27 September 2016 pukul 1.14 dari situs http://globallavebookx.blogspot.co.id/2015/03/pengertian-model-pembelajaransnowball.html

Suprijono. (2009). Diunduh tanggal 27 September 2016 pukul 1.16 dari situs http://mgmppknkabkuburaya.blogspot.co.id/2012/08/artikel-3-penerapan-metodesnowball.html 